\title{
Design and Fabrication of Aluminum Cladding and Curtain Wall of a Sports Club
}

\author{
Muhammad Tayyab Naqash \\ Department of Civil Engineering, Faculty of Engineering, Islamic University of Madinah, Medina, KSA \\ Email: engr.tayyabnaqash@gmail.com, tayyab@iu.edu.sa
}

How to cite this paper: Naqash, M.T. (2019) Design and Fabrication of Aluminum Cladding and Curtain Wall of a Sports Club. Open Journal of Civil Engineering, 9, $1-17$.

https://doi.org/10.4236/ojce.2019.91001

Received: January 7, 2019

Accepted: February 18, 2019

Published: February 21, 2019

Copyright $\odot 2019$ by author(s) and Scientific Research Publishing Inc. This work is licensed under the Creative Commons Attribution International License (CC BY 4.0).

http://creativecommons.org/licenses/by/4.0/

(c) (i) Open Access

\begin{abstract}
The paper discusses the design, fabrication and the execution of the cladding supported by steel trusses and curtain wall of a sports club. The cladding and the curtain walls were subjected to a wind load of $1.2 \mathrm{Kpa}$ considering basic wind speed of $25 \mathrm{~m} / \mathrm{s}$ as per the project specifications. The first part of the paper deals with the cladding work of the canopy that consist of a $4 \mathrm{~mm}$ thick aluminium composite panels supported by steel trusses extended from the main structure. Two types of steel trusses were provided, the main truss connected to the space truss, whereas the intermediate truss connected to channels. Both trusses were spaced at $2.5 \mathrm{~m}$ centre to centre. These trusses were fabricated at factory and transported to the site for installation. The second part of the paper is related to the curtain wall design having Maximum Mullion spacing of $2 \mathrm{~m}$, considered as worst scenario for the design calculations. The maximum Mullion height was $5.55 \mathrm{~m}$, adopted in the calculations with bottom and top pinned connection. The Technal system was adopted for the design of mullions and transoms. Design was carried out using numerical modeling with CSI SAP2000 for cladding and its supporting structures. The bracket was realized and checked for the corresponding induced forces. All the structural systems were found safe according to different acceptance criterion.
\end{abstract}

\section{Keywords}

Aluminum Composite Panel, Curtain Wall, Fabrication, Numerical Modeling, Cladding

\section{Introduction}

The optimum design, execution and construction of building envelop is one of the most critical part of the building as the aesthic of the building which is di- 
rectly related to the façade of the building. When glass is used as glazing material, the great advantage of natural light is achieved that penetrate deeper within the building. The curtain wall façade carried its own weight in addition to the external loads acting on it. These loads are then transferred to the main structure. The wall transfers wind loads to the main building structure through connections at floors or columns. A cladding or a curtain wall is designed to resist air, water infiltration, sway induced by wind and seismic forces acting on the building together with its self-weight. Furthermore, it is to be underlined that moisture control, solar light under extreme high temperatures such as medal east, air leaks in the events of extreme winds and thermal losses and gains are all affected by the design and construction of the building façade. Sandwich panel construction techniques have experienced considerable development in the last 40 years. Previously, sandwich panels were considered products suitable only for functional constructions and industrial buildings. However, their good insulation characteristics, their versatility, quality and appealing visual appearance, have resulted in a growing and widespread use of the panels across a huge variety of buildings. In early $19^{\text {th }}$ Century with the development of large glass panels buildings were constructed with exterior load bearing walls thereby supporting the load of the entire structure and became more common from the 1930's when aluminium was made available as a construction material for the first time. In the mid of $19^{\text {th }}$ century Glass curtain wall started to be used as non-load bearing structure due to the development and widespread use of steel and later reinforced concrete. The exterior walls could be non-load bearing and thus much lighter and more open than the masonry load bearing walls of the past. Later at $20^{\text {th }}$ century, it tended to be unique and custom-made, fabricated individually from the cast iron, rolled steel and plate glass that just began to appear as industrialized production. This gave way to increased use of glass as an exterior façade, and therefore the modern day curtain wall was born [1] [2]. The versatility of aluminum metal is complemented by the flexibility of the extrusion process. Other metals can be extruded but few with the ease like aluminum and its alloys [3]. Aluminum Cladding Panels (ACPs) are frequently used for external cladding or facades of buildings, insulation, and signage. ACP has been used as a light-weight but very sturdy material in construction, particularly for transient structures like trade show booths and similar temporary elements. The design report dealt here is related to the steel, aluminum and glass work for a sports club. Views after renovation and during execution work for the sports club are shown in Figure 1 and Figure 2.

Figure 3 shows a partial roof plan of the trusses extended from the main structure. Spacing of the trusses are depicted in the same Figure 3. In Figure 4, models of primary and secondary trusses generated in SAP2000 are shown. A perspective view showing the cladding can also be seen in Figure 4. These trusses are fabricated in workshop in batches and then transported to the site (See Figure 5 left) for final installalation as shown in Figure 5. 

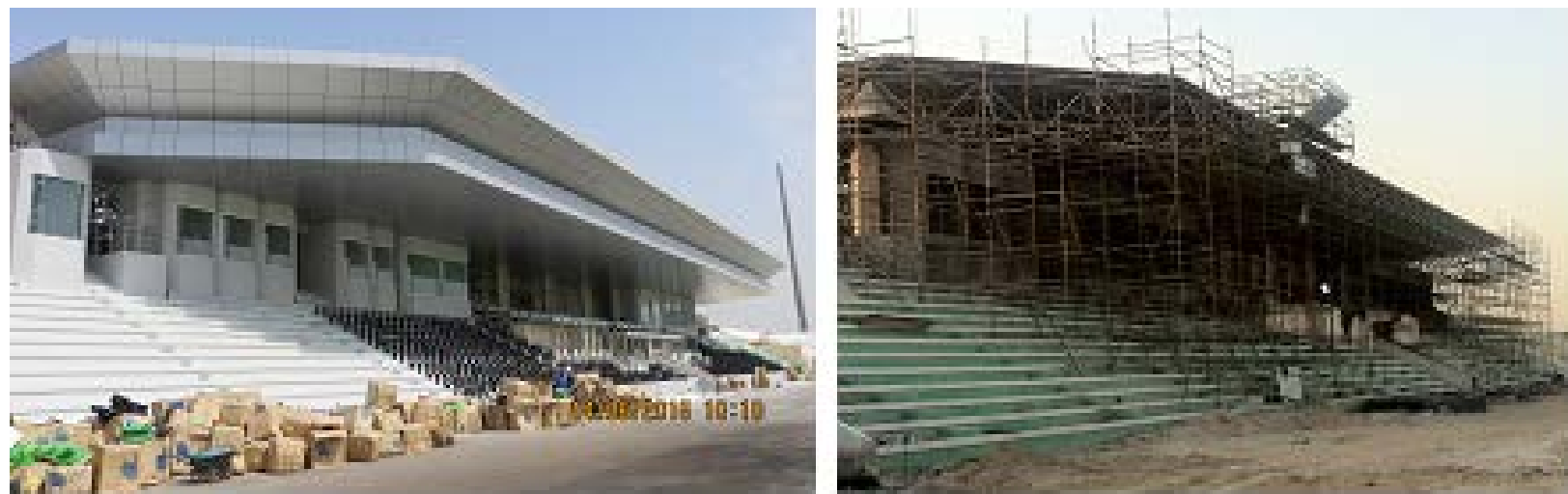

Figure 1. Views of the cladding work (left) after finishing of the cladding and (right) during the execution.
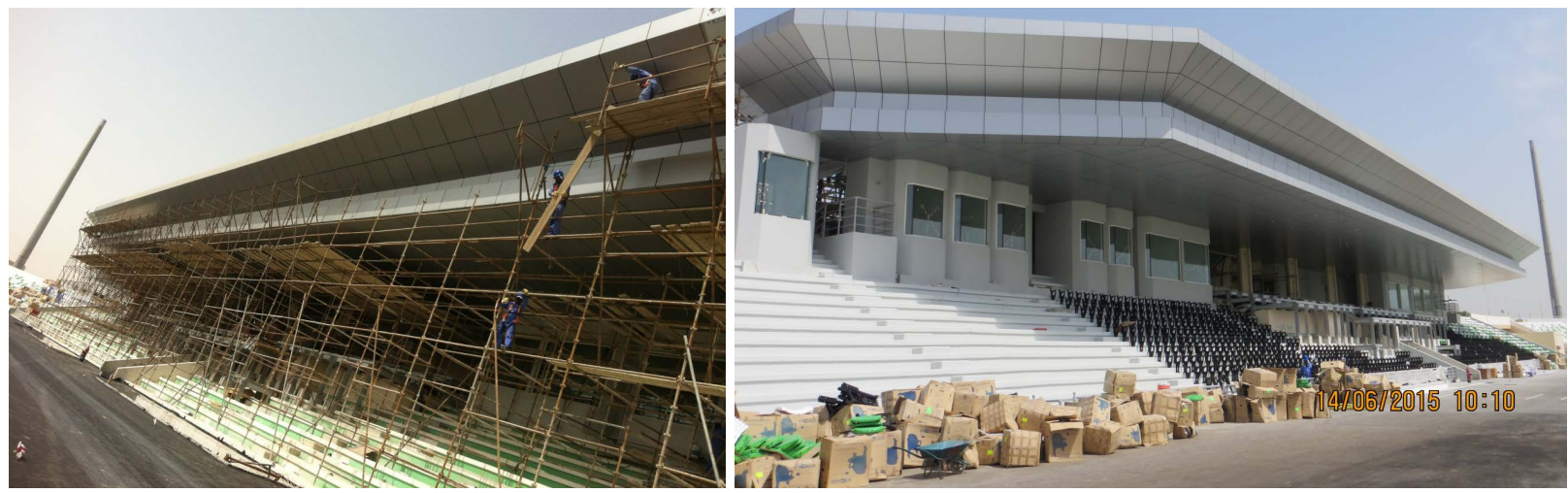

Figure 2. View of the canopy after the cladding work (left) and after the installation) (right).

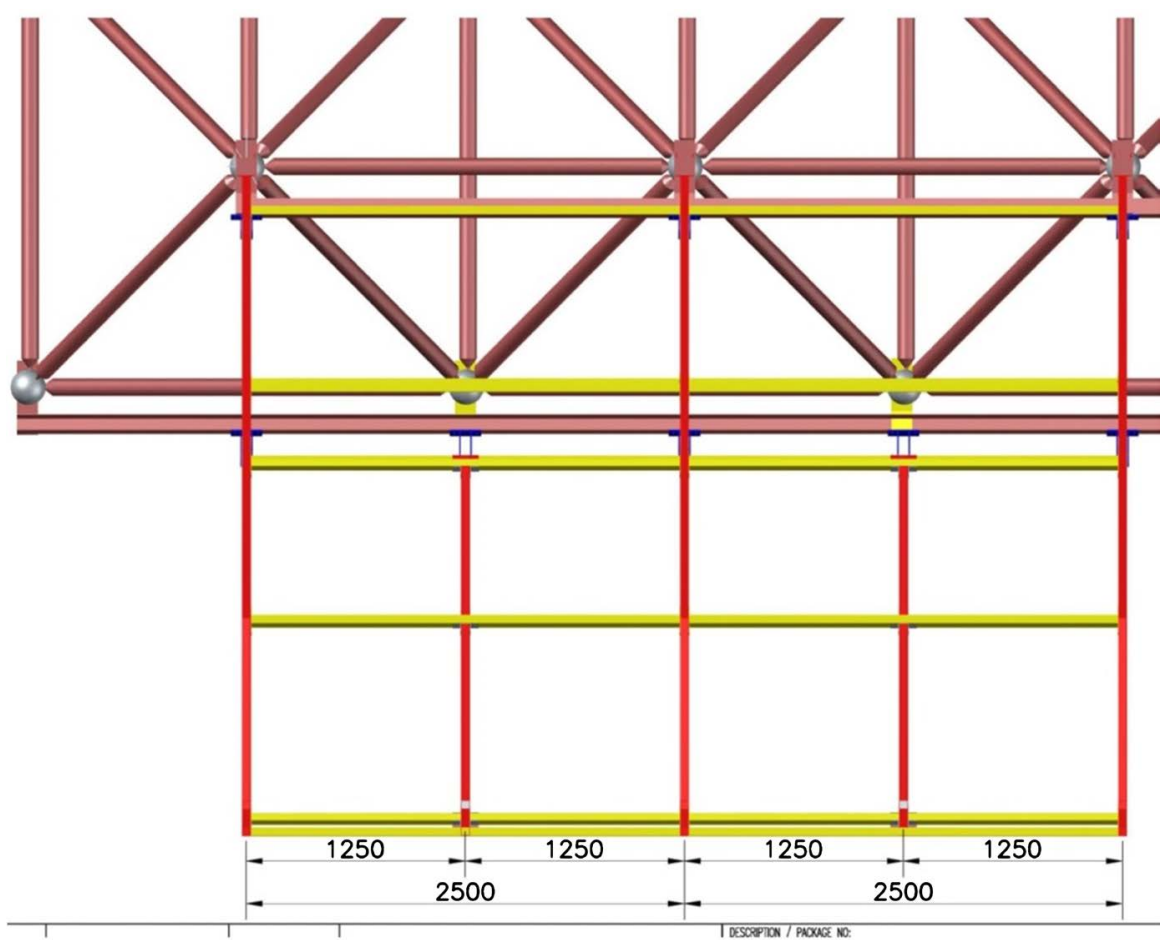

Figure 3. Plan of the extended supporting structure. 


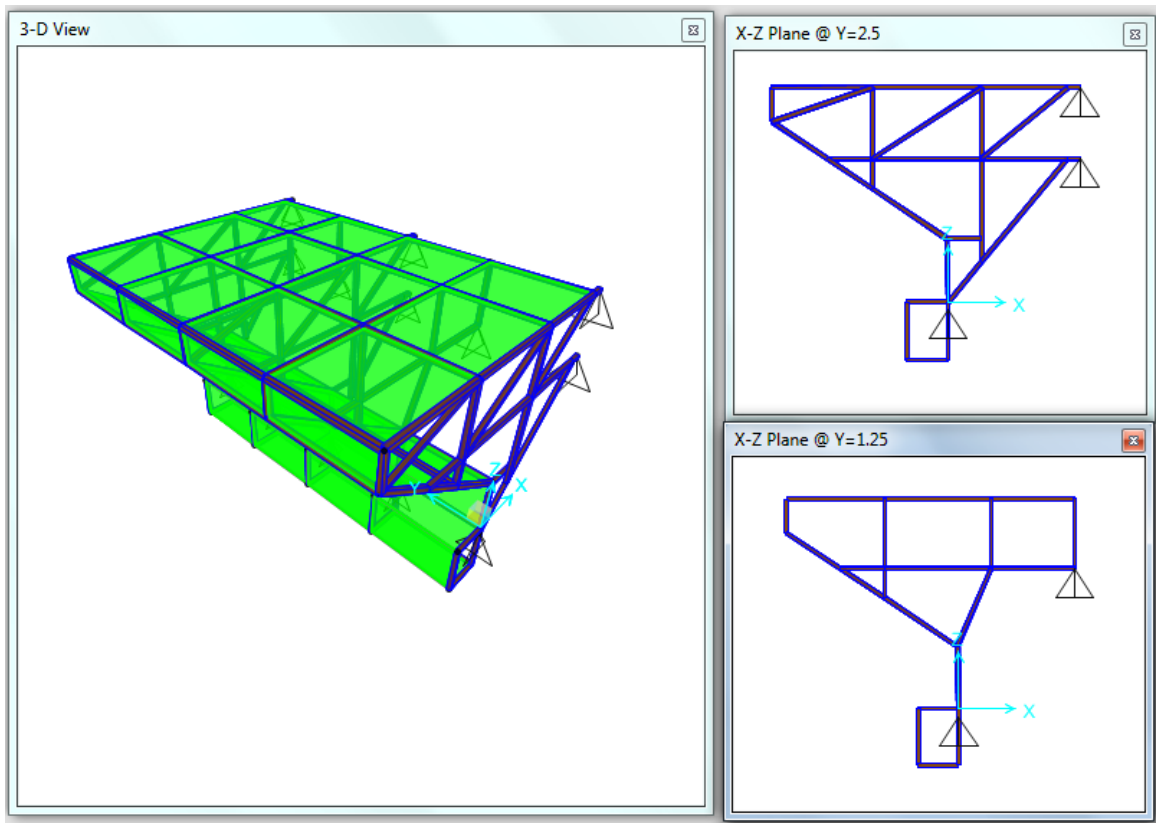

Figure 4. View of the cladding supported structure.
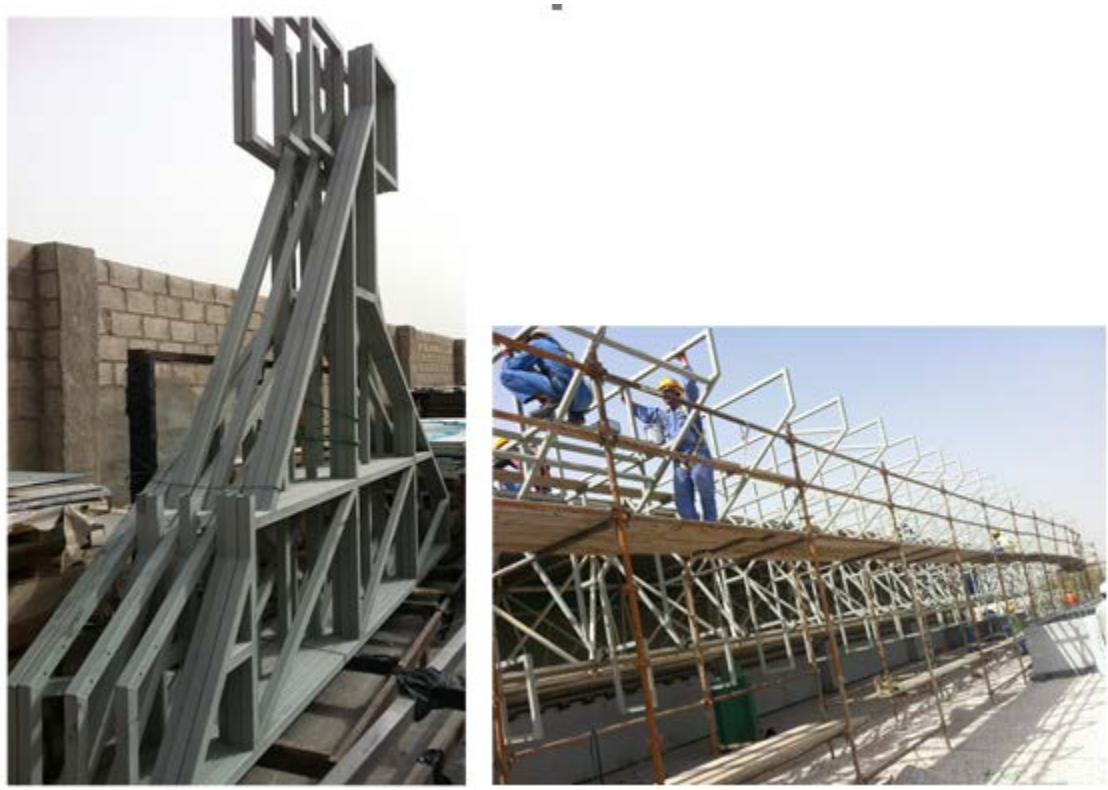

Figure 5. Trusses ready at the workshop to be delivered to the site for installation (left) and View of the cladding supported trusses (Erection in progress) (right).

\section{Design Criteria}

Since several materials are used here, therefore a single code is not prescribed here. Therefore, regarding the Ultimate Limit State (ULS) a permissible strength of $160 \mathrm{MPa}$ [4] [5] is considered for Aluminum and $275 \mathrm{Mpa}$ for steel. With reference to the serviceability limit state a permissible deflection under dead and wind load of span/90 is considered for Aluminum cladding panel whereas permissible deflection under dead and imposed load of span/200 is considered [6]. 
The overall deflection of the cantiever trusses is considered as span/180. The deal load for Aluminum cladding panel and SHS tubes is calculated by the software SAP 2000 [7]. The wind load of $1.2 \mathrm{KN} / \mathrm{m}^{2}$ is adopted as per the project specifications. When designing Aluminum structures to British Standards the relevant load factors are specified in BS 8118: Part 1: Clause 3.2.3 Factored loading [4] [5]. According to Clause 3.2.3 the overall load factor $\gamma_{f}$ is calculated as: $\gamma_{f}=\gamma_{f 1} \times \gamma_{f 2}$.

Where $\gamma_{f l}$ and $\gamma_{f 2}$ are partial load factors for standard design situations with the imposed load or wind action that give the most severe loading action on the structure or components. In contrast to BS 8118 the load factors for designing Aluminum structures are given in the Eurocode 0 or EN 1990 as Eurocode 1 or EN 1991 [8] [9] with the use of National Annex. Furthermore it is seen that design loads generated with the procedure of Eurocode 0 generates higher values for the design actions for the ULSs [10]. The design load combinations in the present case are the various combinations of the load cases for which the model needs to be analysed. Since curtain walls consist of Aluminum material therefore according to the BS 8118 code are assumed subjected to dead load (DL) and Wind load (WL). The load combinations that need to be considered are 1.2 DL and 1.2 $\mathrm{DL} \pm 1.2 \mathrm{WL}$. Nevertheless since the supporting structure are steel tubes and also in the connections steel bolts etc are used therefore in all verifications load combinations are amplified with a load factor of1.4 as per BS 5950 [11]-[16].

\section{Numerical Modeling and Results for Cladding}

The complete geometry (model, meshing, member releases and loading) with the assumptions for the typical Aluminium cladding panel is shown in Figure 6.

The structural calculations for the typical area of the cladding are presented here. This govens the design for the rest of the curtain wall panels.

Maximum Induced bending stress as shown by Figure 7 (left) in the cladding panel under ULS is 3.2 Mpa < The allowable bending stress equals $125 \mathrm{Mpa}$. Regarding the acceptance criteria for the allowable deflection under DL + WL for panels should not exceed span/90 that equals $700 / 90=7.8 \mathrm{~mm}>2.8 \mathrm{~mm}$ as shown in Figure 7 (right). This concludes that the cladding panels are safe to winstand the desing ultimate loading under the wind load combinations. Therefore the cladding panels are safe for both ultimate limit states and serviceability limit states.

The demad to capacity ratios for all the steel members are found less than unity see Figure 8 (left), therefore all members are passed. Furthermore maximum Induced stresses (see Figure 8 (right)) in the steel frames under ultimate load conditions equals $58 \mathrm{Mpa}<$ The allowable bending stress equals $275 \mathrm{Mpa}$.

Maximum deflection in the framing members as evident from the Figure 9 equals $2.7 \mathrm{~mm}$. Since the Limiting value is Span $/ 180=3000 / 180=16.8 \mathrm{~mm}$. Hence the members satisfied the serviceability criteria.

In this section the demand to capacity ratios for both main as well as intermediate truss members are addressed (See Figure 10). The member numbering (See Figure 11), bending moment diagram (See Figure 12) under ULS and shear 

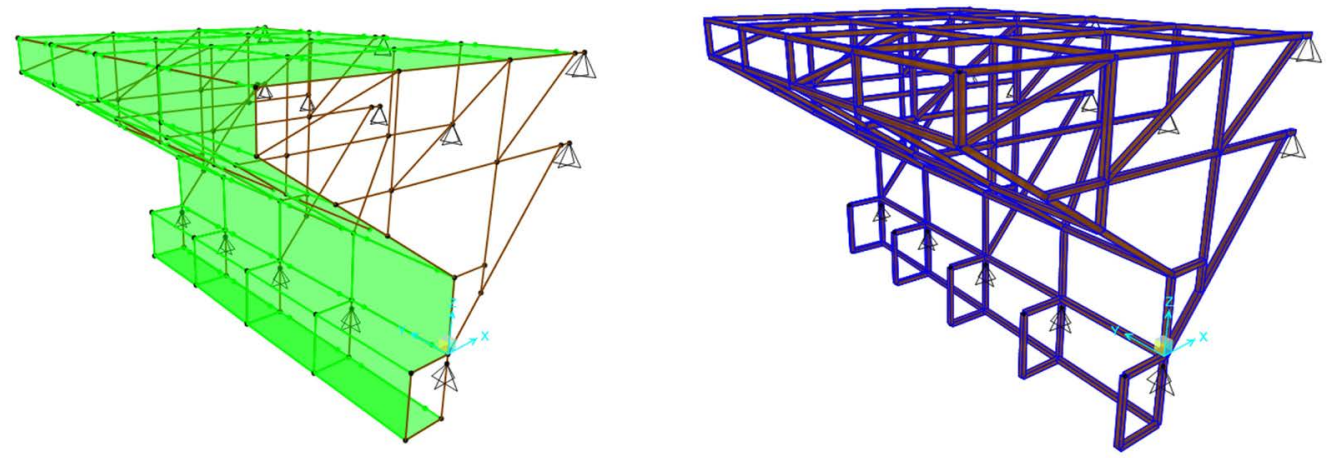

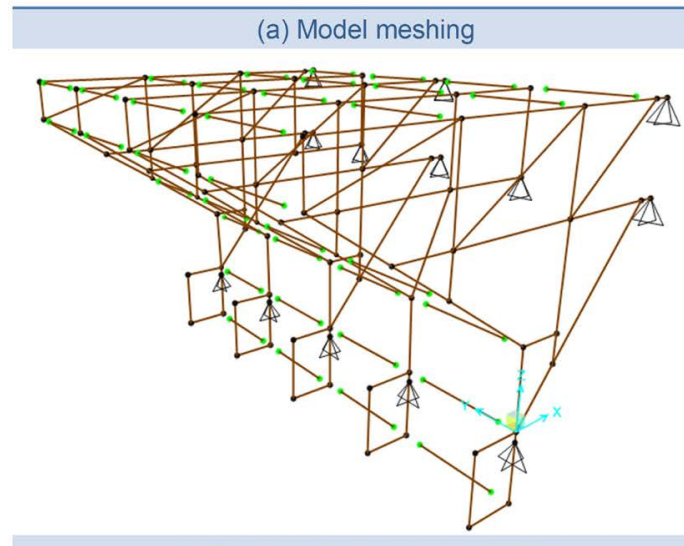

(c) Frame releases and restraints

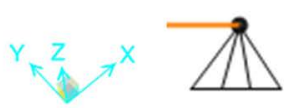

(e) Restraints and axes (b) Frame Model

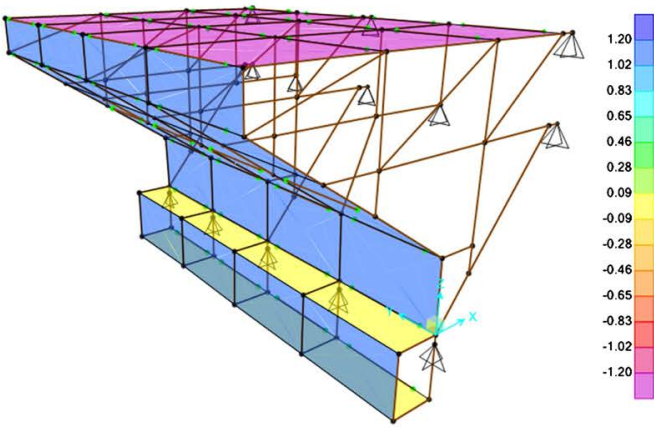

(d) Wind Loading surface $(1.2 \mathrm{kPa})$

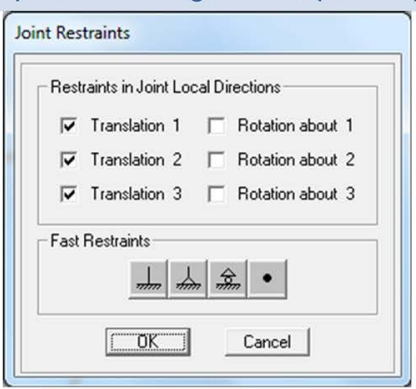

(f) Restraints condition

Figure 6. Model meshing, (a) Model, (b) truss Model 3D, (c) member releases and restraints, (d) Wind Loading surface (1.2 kpa), (e) Restraints condition and (f) Axes.
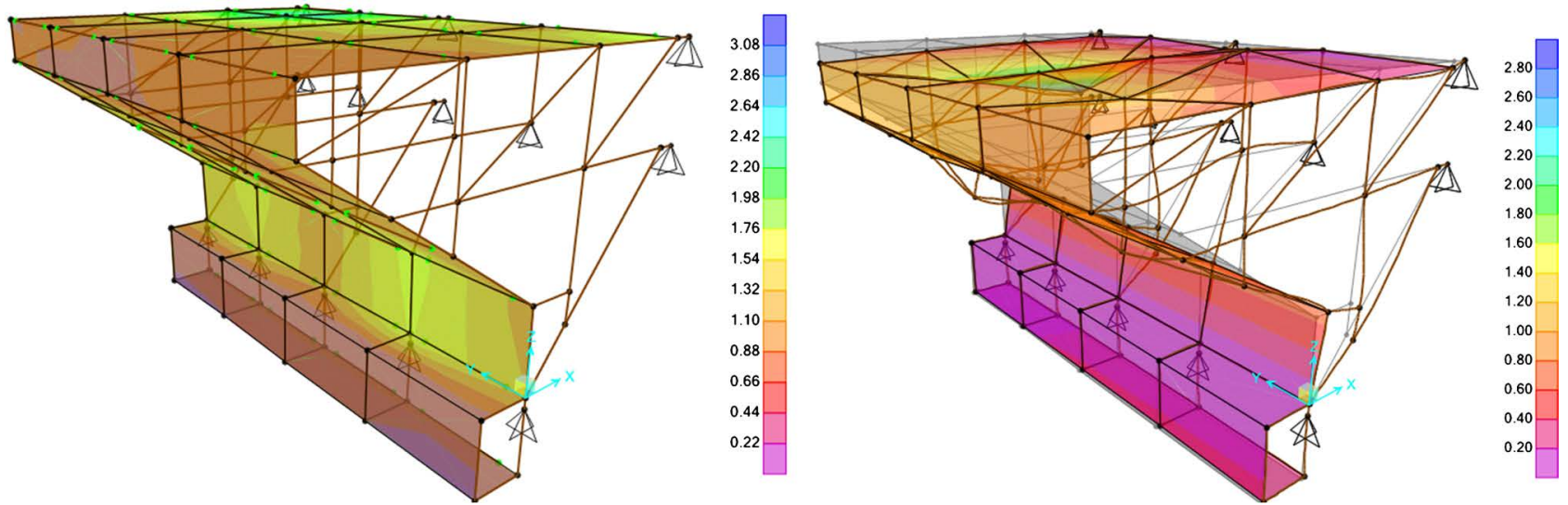

Figure 7. Stresses in Panel under ULS (left) and Deflection in Panel under SLS (DL + WL), scaled to 200 for clear visibility (right). 

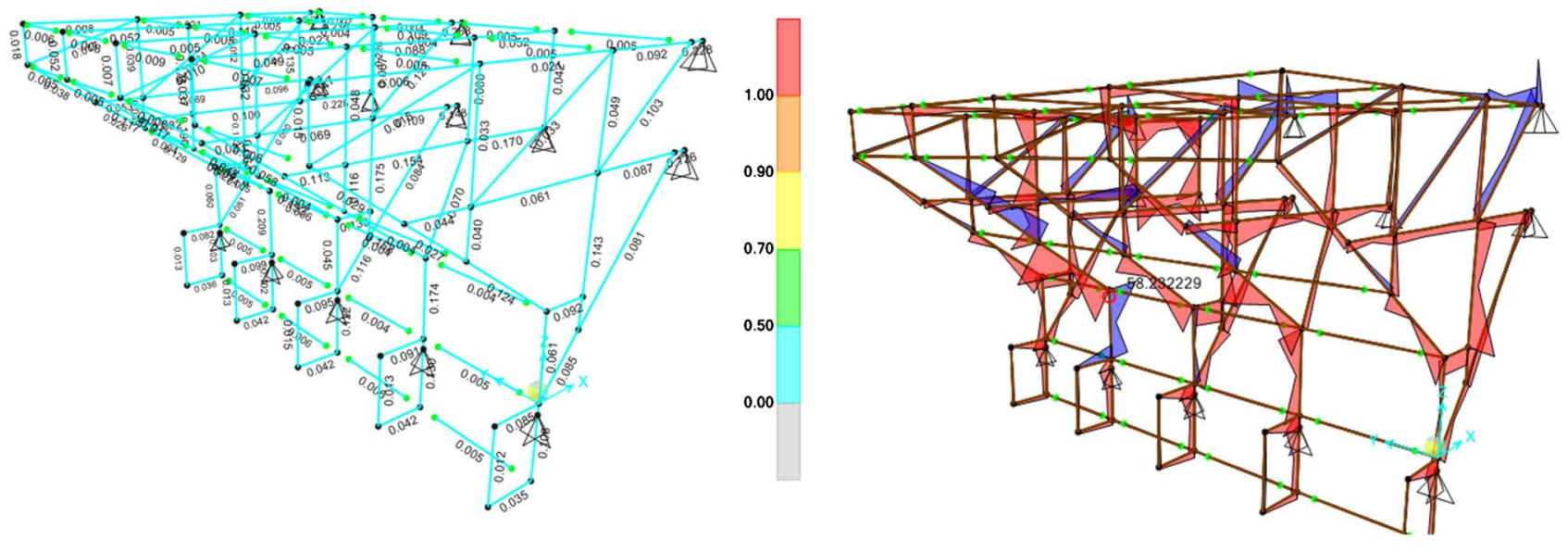

Figure 8. Demand to Capacity ratios of truss members (D/C $<1.0)$ and (right) Stresses under ULS (left).

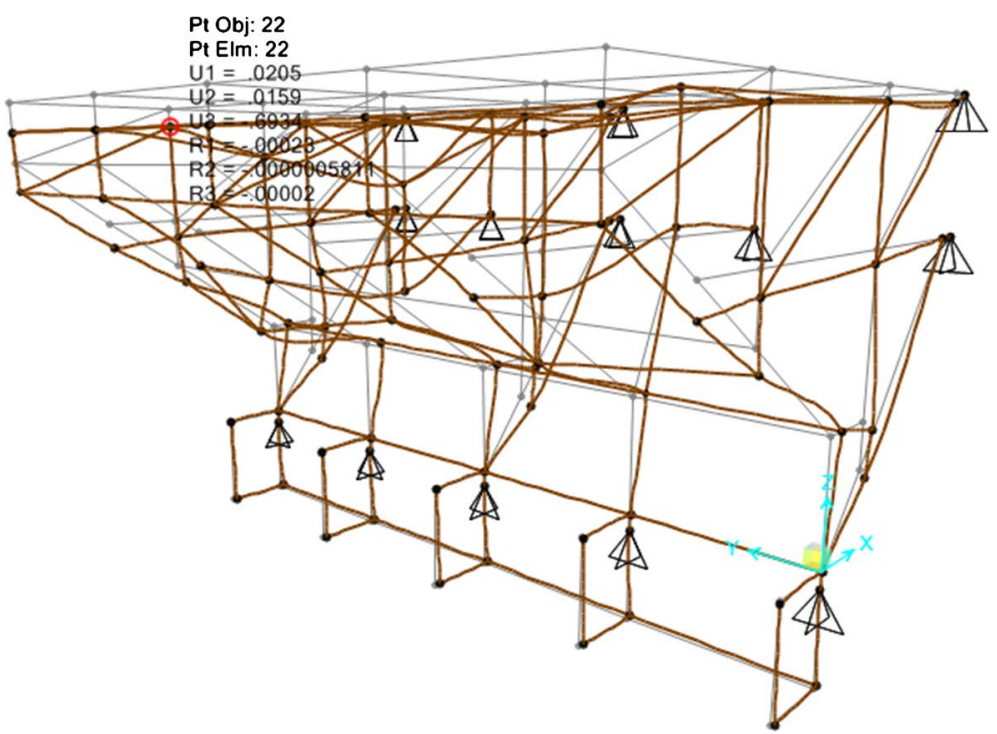

Figure 9. Deflection under SLS scaled to 200 for clear visisbility.
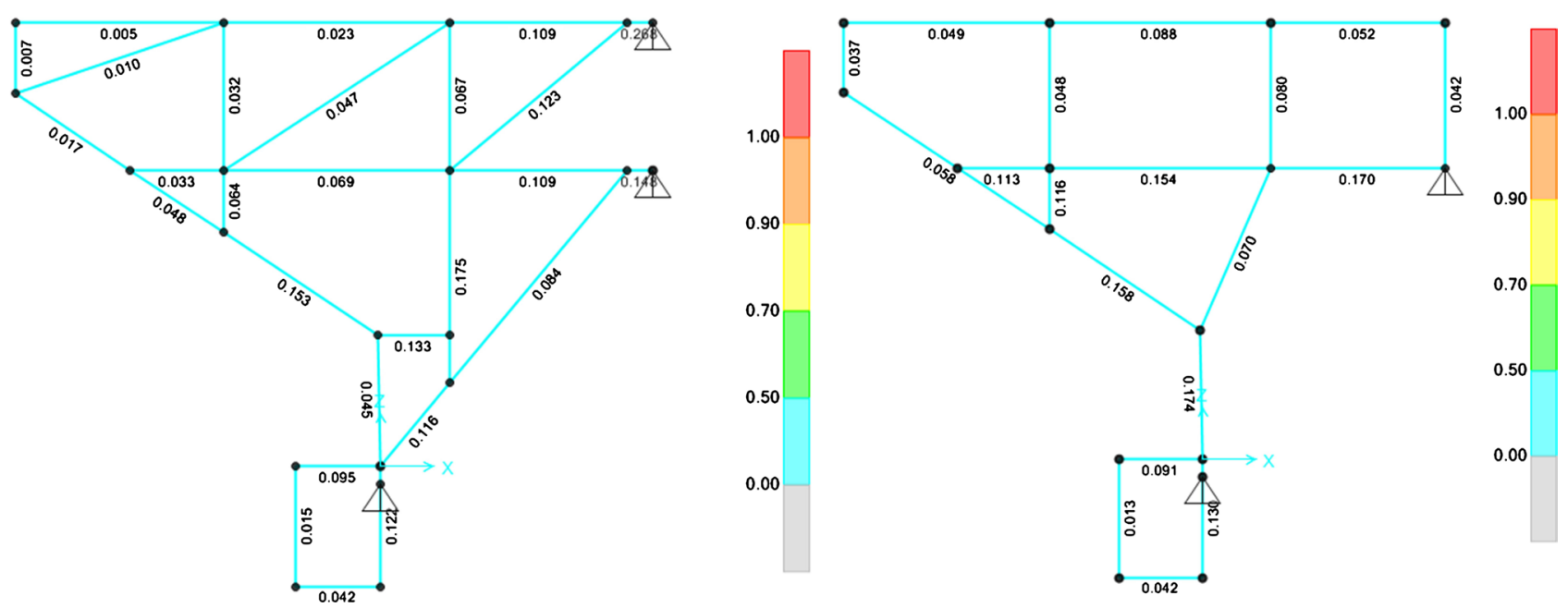

Figure 10. Demand to capacity ratios of the main truss members (left) and Demand to capacity ratios of the intermediate truss members. 

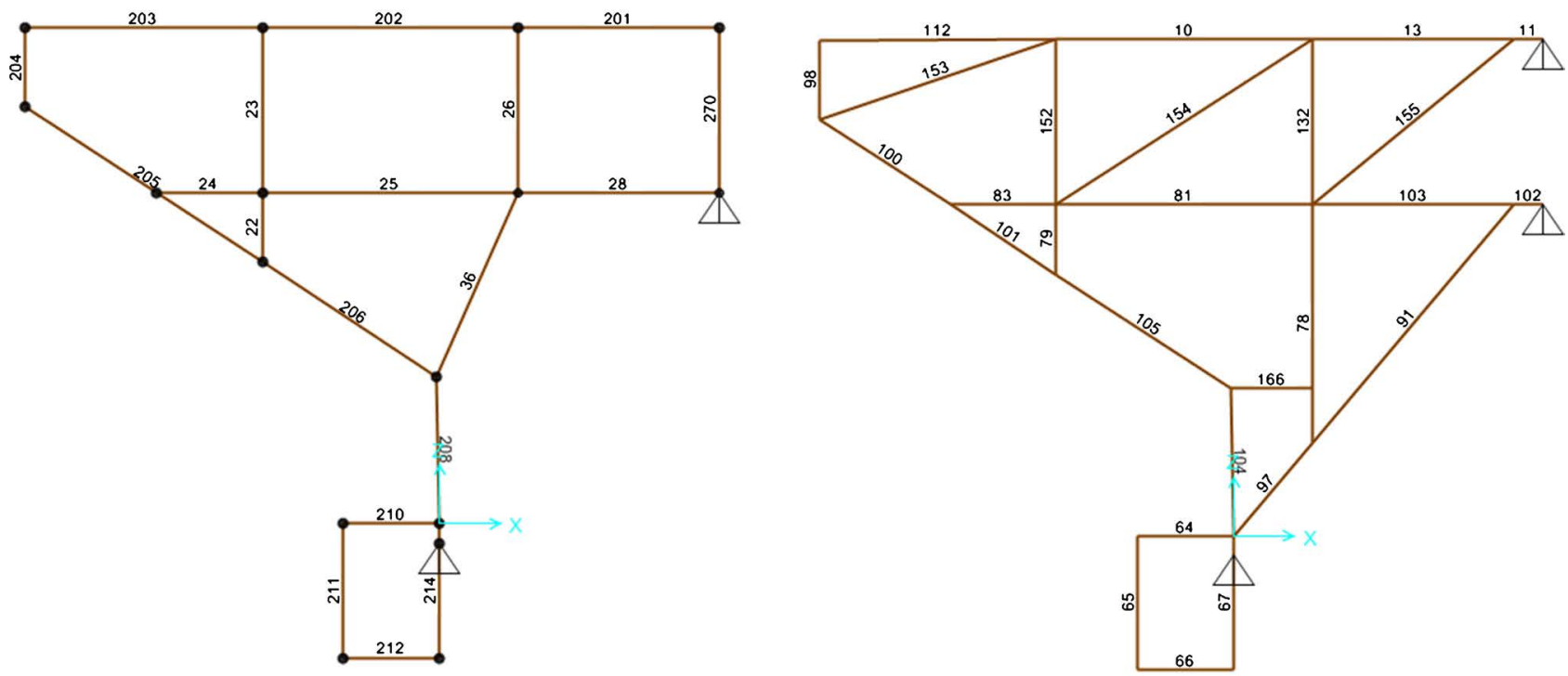

Figure 11. Member numbering for intermediate truss (left) and main truss (right).

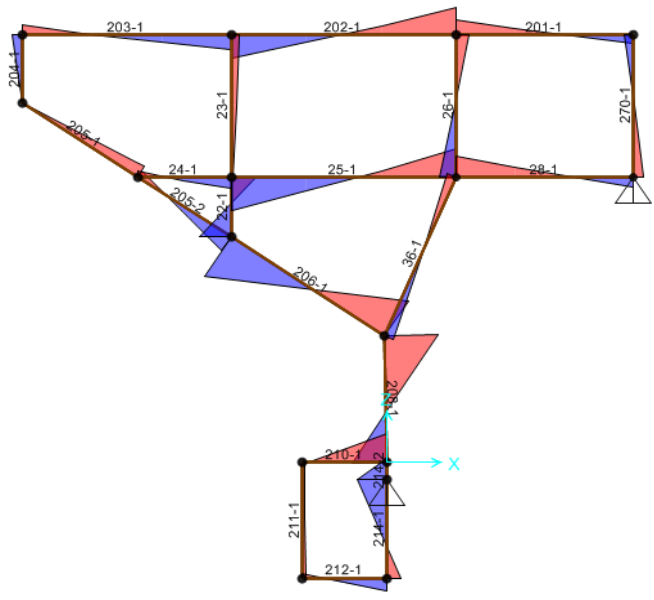

- Moment 3-3 Diagram (UIS)

Figure 12. Bending moment diagram under ULS in the truss (Max $0.51 \mathrm{KNm}$ ) for intermediate truss (left) and main truss (right).

force diagram (See Figure 13) under ULS are shown in this section.

Maximum shear induces is $3.45 \mathrm{KN}$, Maximum moment is $0.508 \mathrm{~K} \mathrm{Nm}$ and Maximum axial force is $12.1 \mathrm{KN}$ (See Figure 14). It is worthy noting here, that the trusses are fully welded, therefore can transfer the applied forces. The forces in the horizontal runners (spanning between the trusses) are bolted through M8 bolts.

\section{Curtain Wall Design}

In this section for the paper the design of the curtain wall is addressed. The external elevation of the curtain wall consists of $24 \mathrm{~mm}$ double glazing glass unit (6 $\mathrm{mm}$ tempered glass $+12 \mathrm{~mm} \mathrm{~mm}$ air gap spacer $+6 \mathrm{~mm}$ tempered glass) as shown in Figure 15. 

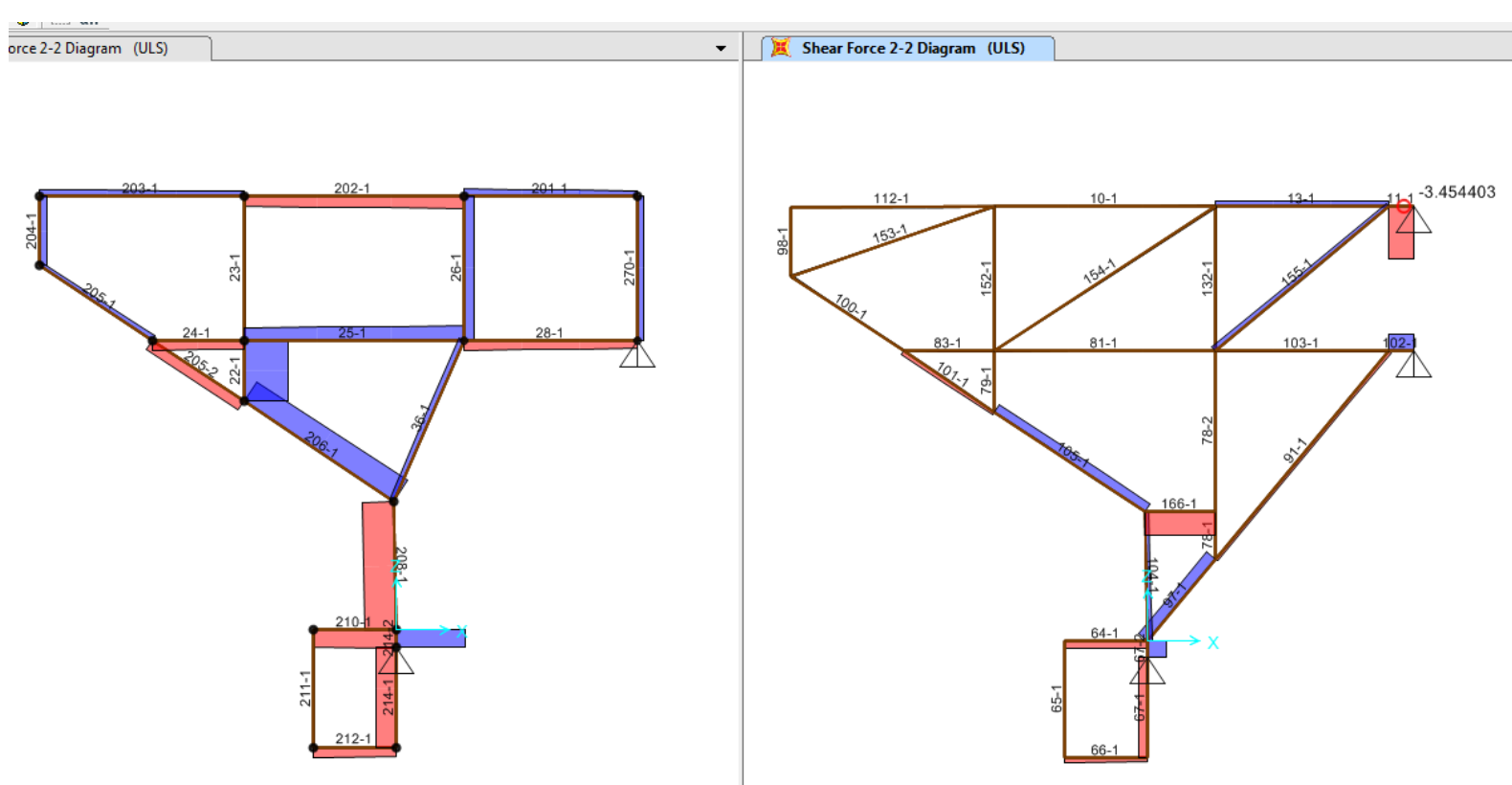

Figure 13. Shear forces in the framing members under ULS (Max $3.45 \mathrm{KN}$ ) for intermediate truss (left) and main truss (right).
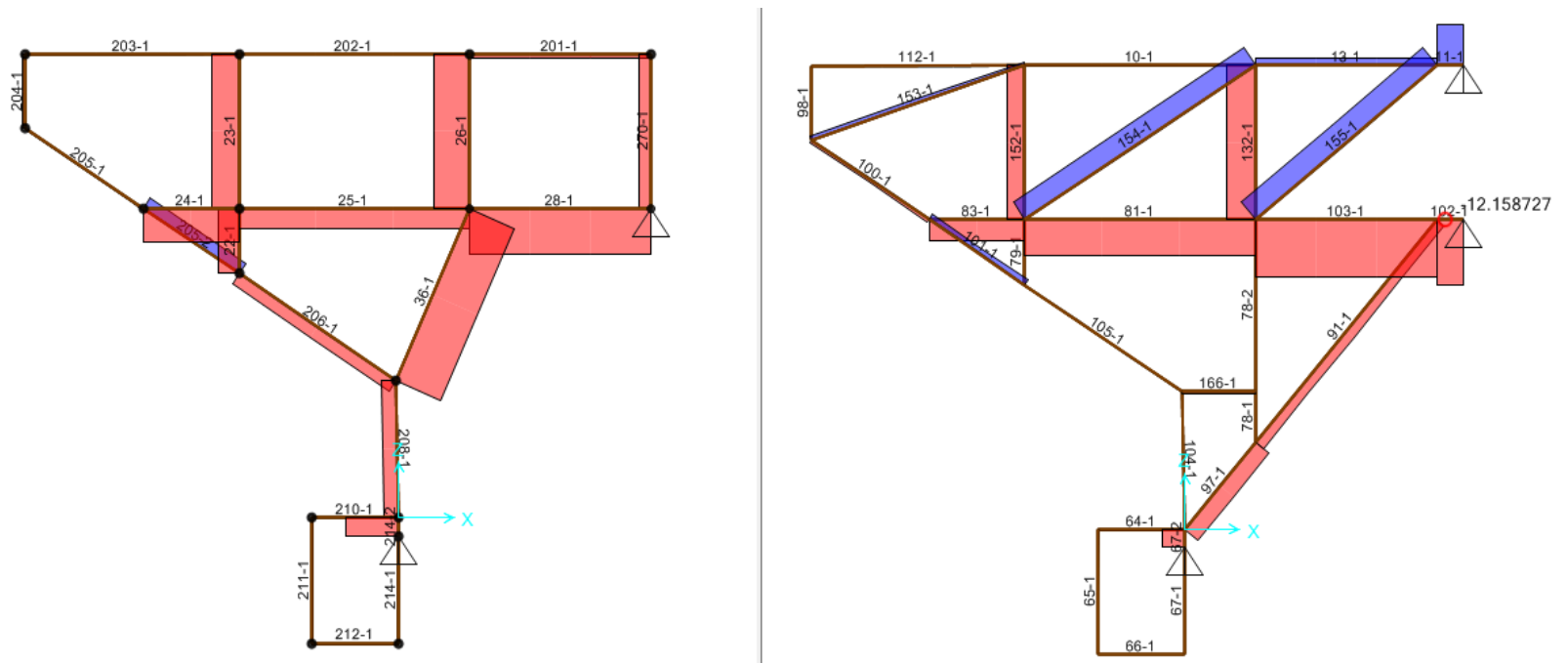

Figure 14. Axial forces in the framing under ULS (Max 12.1 KN) for intermediate truss (left) and main truss (right).

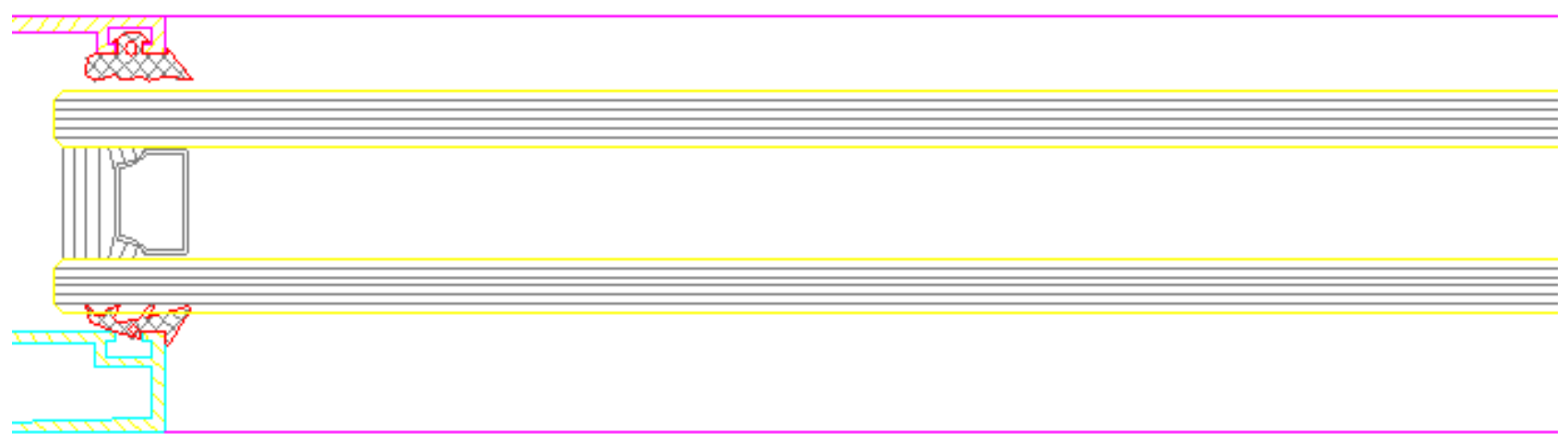

Figure 15. DGU Glass thicknesses $(6 \mathrm{~mm}+12 \mathrm{~mm}$ air gap $+6 \mathrm{~mm})$. 
The various checks related to strength and deformability obtained from the numerical model as shown in Figure 16 [7] have been carried out for glass and Aluminum mullions. The structural elements, glass and brackets been found SAFE according to different acceptance criterion [17] [18] [19]. Maximum Mullion spacing (Maximum Transom Length) is $2 \mathrm{~m}$ (See Figure 17 for elevation and Figure 18 for plan), therefore it is considered as worst scenario for the design calculations. The maximum Mullion height is $5.55 \mathrm{~m}$, therefore it is adopted in the calculations with bottom as completely pinned in all directions connection
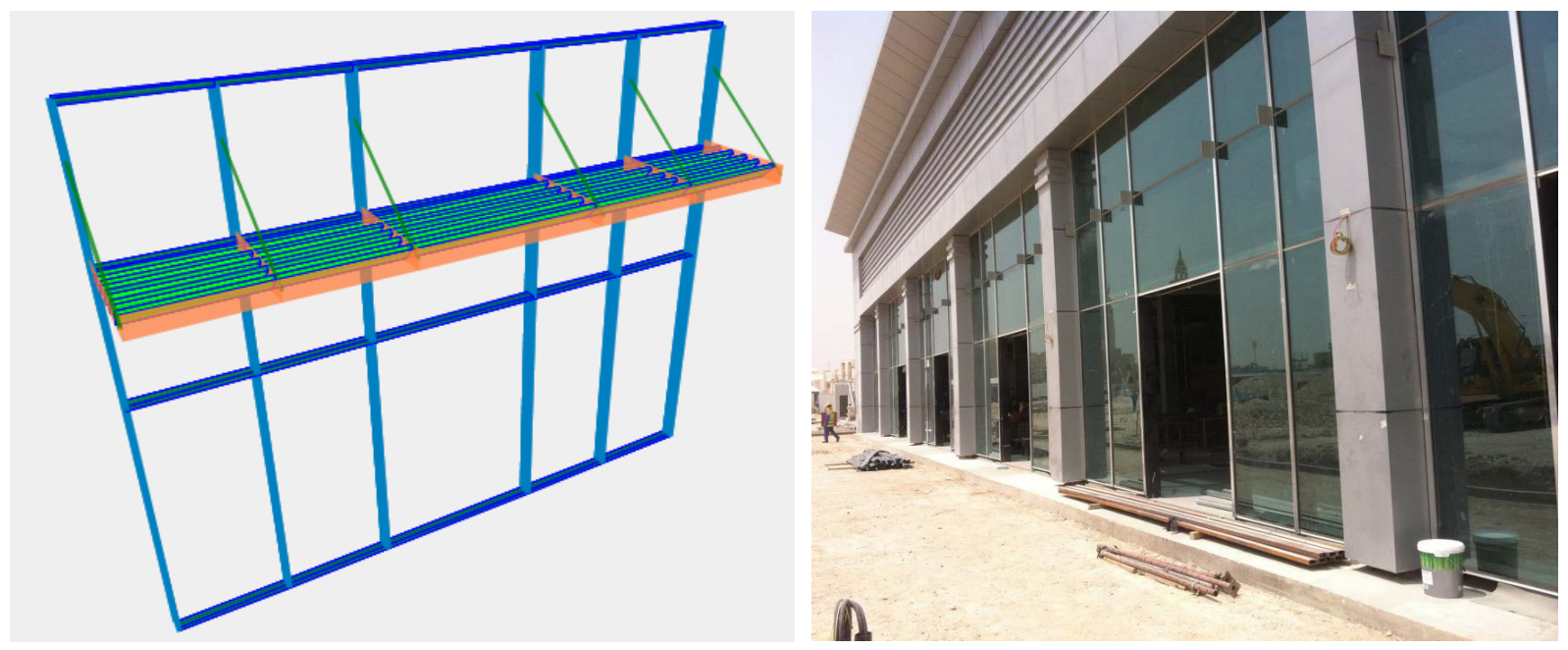

Figure 16. (left) Main Entrance Elevation (right) Curtain wall isometric view.
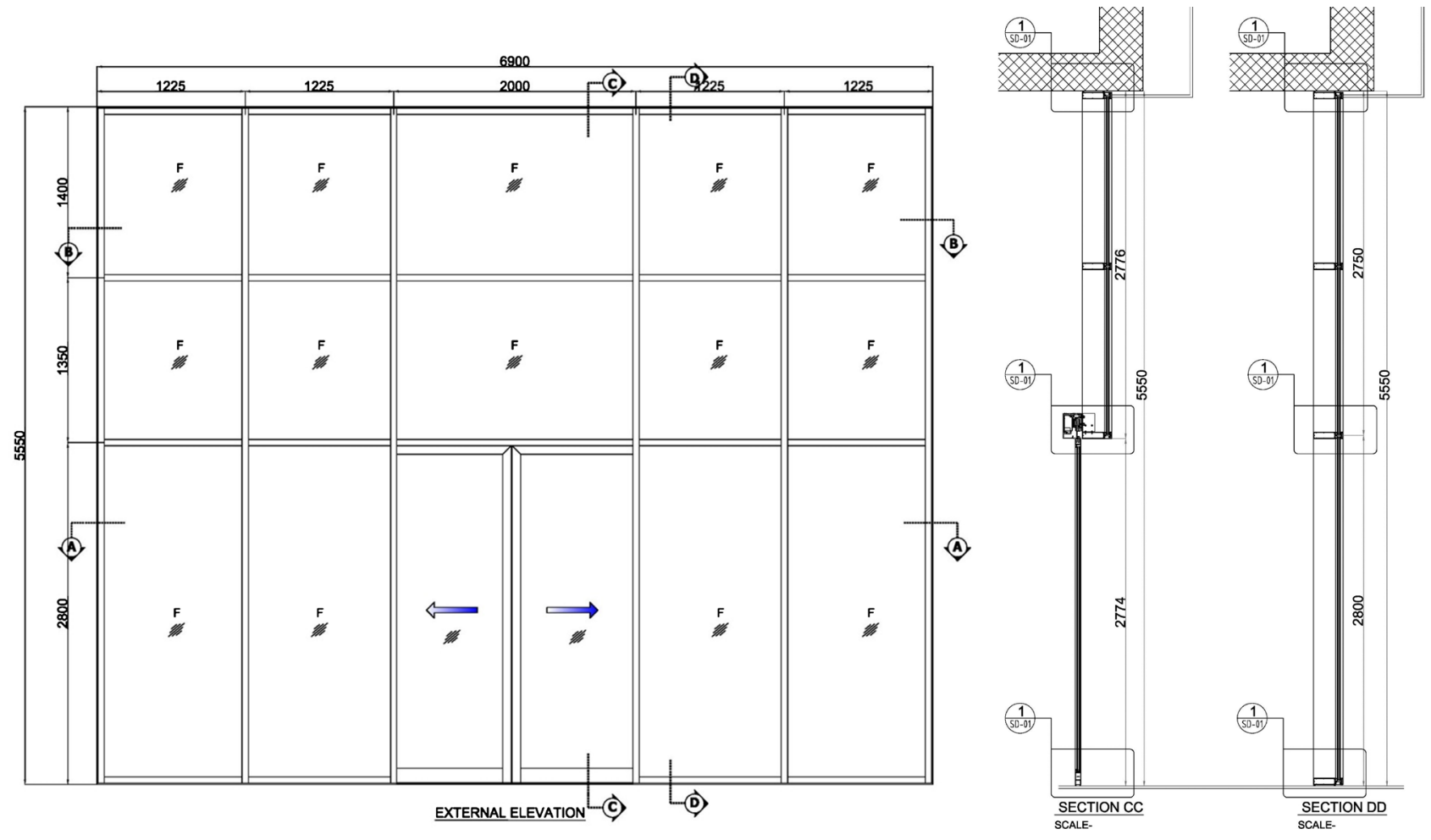

Figure 17. Main Entrance curtain wall (left) Elevation and (right) Section. 

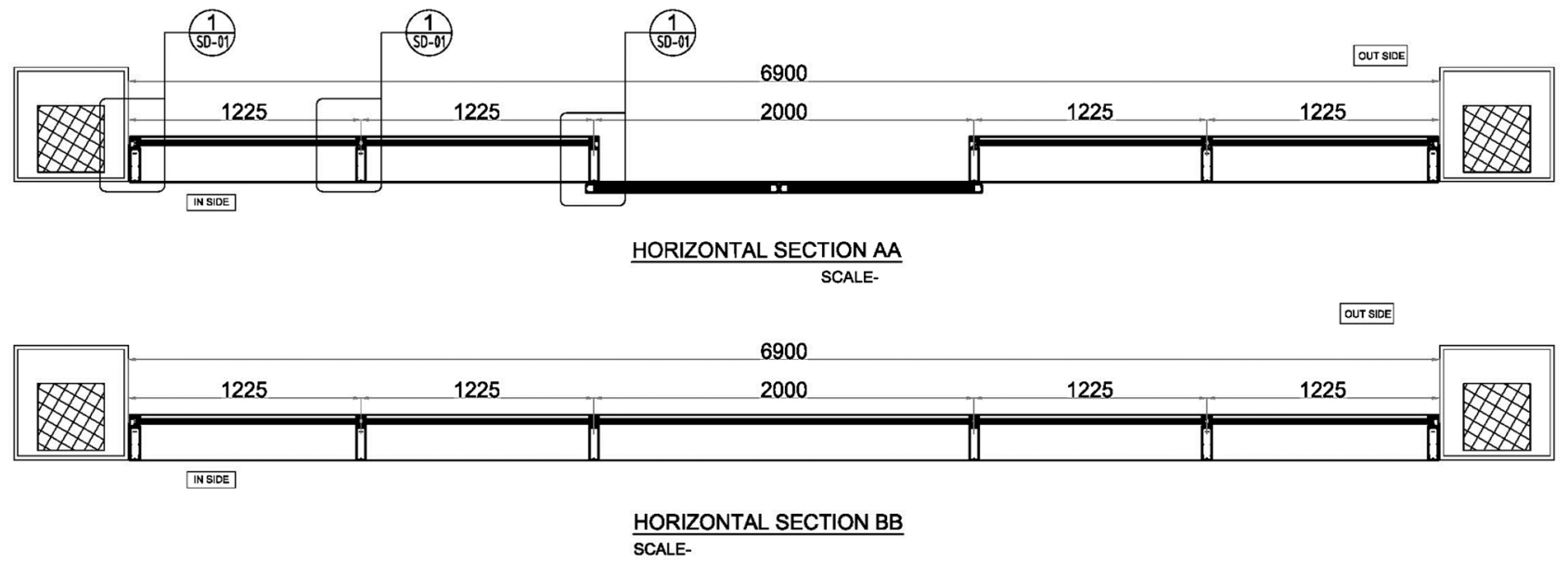

Figure 18. Plan of curtain wall.

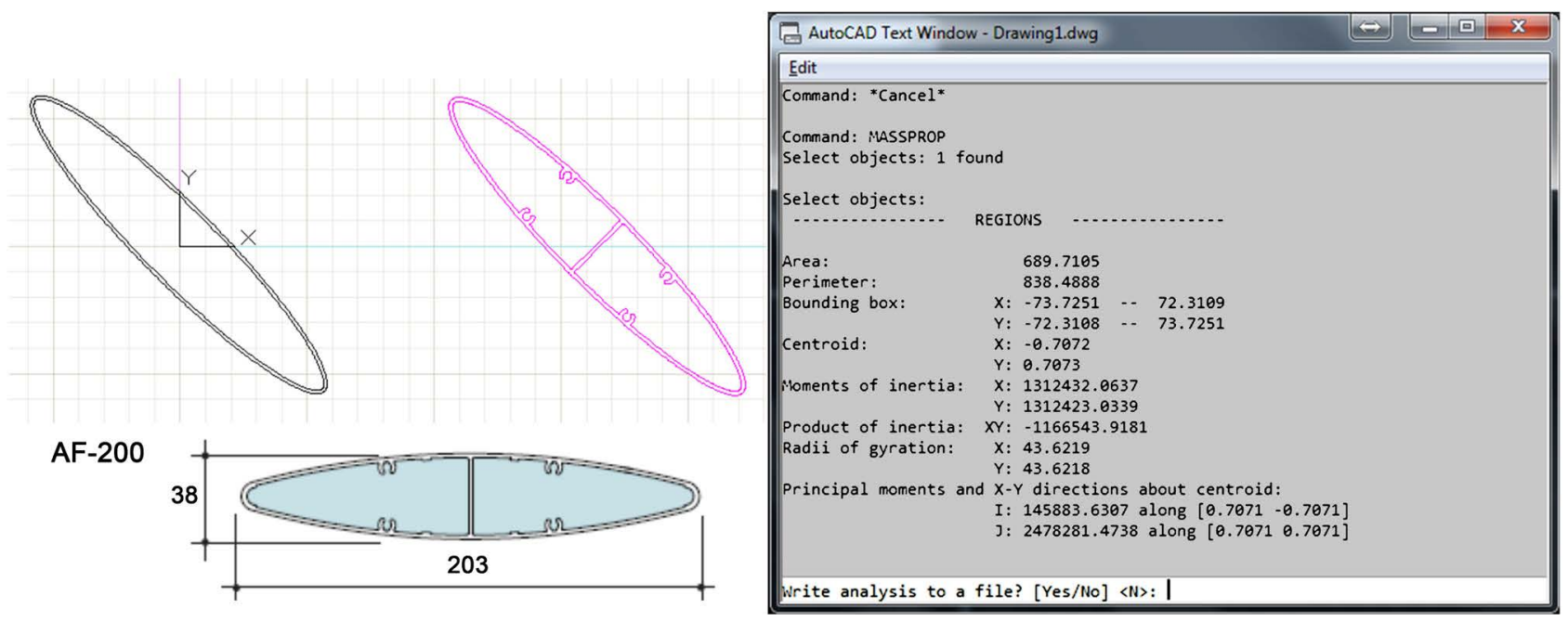

Figure 19. (Left) Louver profiles (right) Geometric properties of louvers.

and top pinned only in one direction (transferring only wind) as shown in the forthcoming sections of the report, The system used for the mullions and transoms profile is Technal [20].

C/S Airfoil blades [21] are extruded in grade 6063-T6 Aluminium allay, the Louver profiles and the corresponding approximate geometric properties of louvers are shown in Figure 19.

\section{Numerical Modeling and Results for Curtain Wall}

In this section numerical modeling and results for the adopted curtain wall is addressed. The curtain wall model, numerical 3D model, memebers releases for the truss, restraints condition and axes of the curtain wall is shown in Figure 20.

The structural calculation for the typical panel is presented here being the dimension of which will govern the design for the rest of the curtain wall. Figure 21 shows curtain wall model, numerical 3D model, wind loading on the surface and restraints condition. 


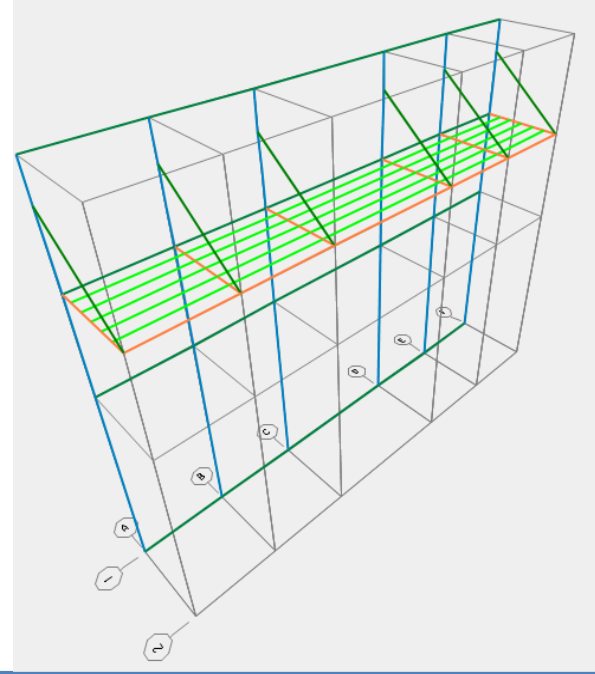

(a) Model

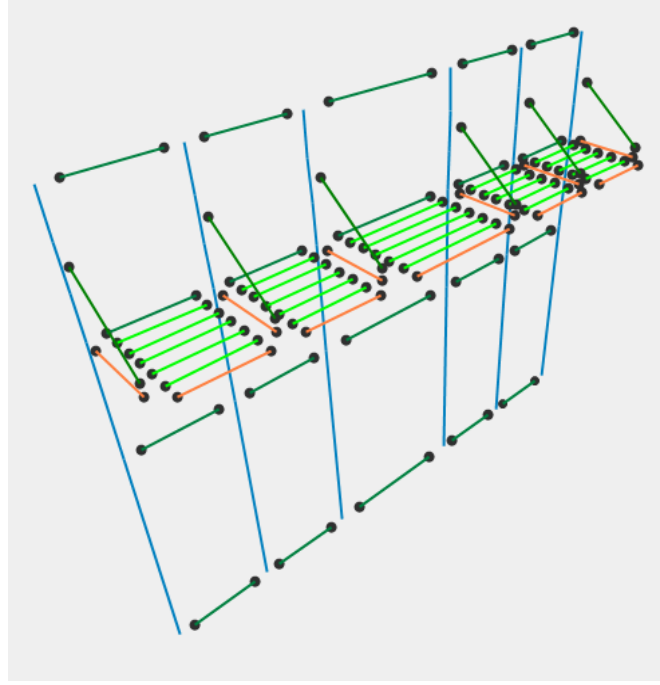

(c) Frame releases and restraints

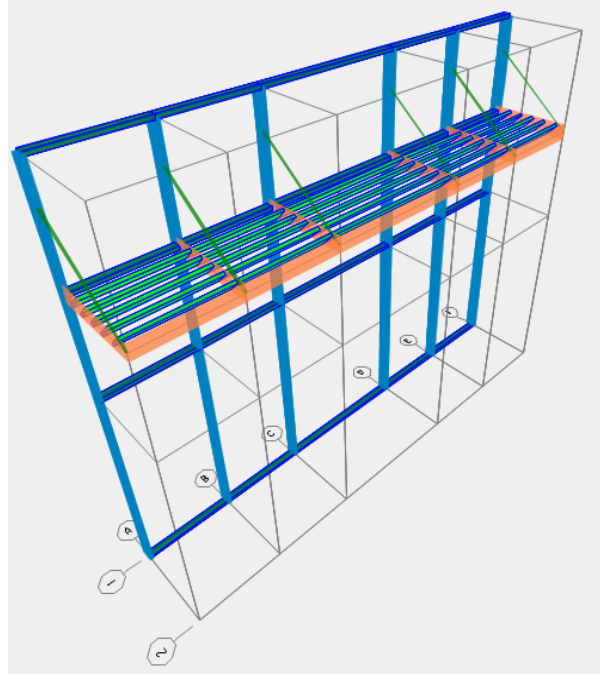

(b) Numerical Model 3D

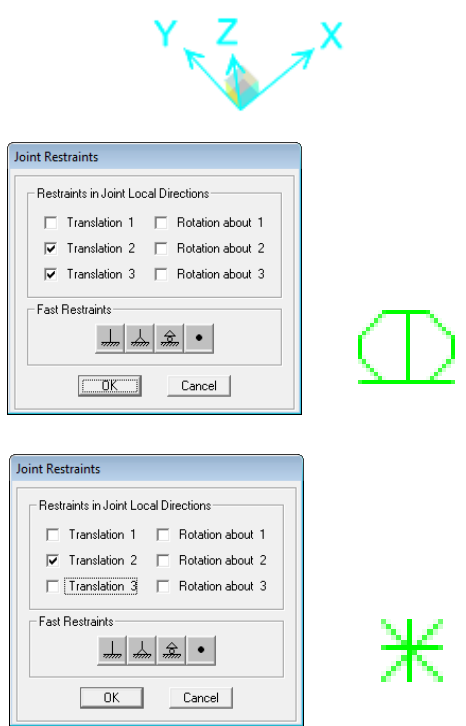

(d) Restraints condition

Figure 20. Curtain wall (a) Model, (b) Numerical 3D Model, (c) truss releases, (d) Restraints condition and (e) Axes.

The glass panel DGU $(6 \mathrm{~mm}+12 \mathrm{~mm}$ (space) $+6 \mathrm{~mm}=24 \mathrm{~mm})$ resting on mullions and transoms grid of as shown below is checked for strength and deflection. Conservatively, it is assumed to be without the air gap.

Maximum Induced bending stress in the glass under ULS as shown in Figure 22 (left) is $16.8 \mathrm{Mpa}<$ The allowable bending stress = 50 Mpa. Maximum Induced deflections as shown in Figure 22 (right) in the glass under SLS is $19 \mathrm{~mm}$. Whereas the Acceptance criteria for allowable Deflection under DL + WL $=$ Span/60 equals $2000 / 60=33.3 \mathrm{~mm}>22.4 \mathrm{~mm}$. The glass panels are Safe for both ultimate limit states and serviceability limit states. In the following section, mullions and transoms checks are carried out under the adopted acceptance criteria for strength and deflections. 


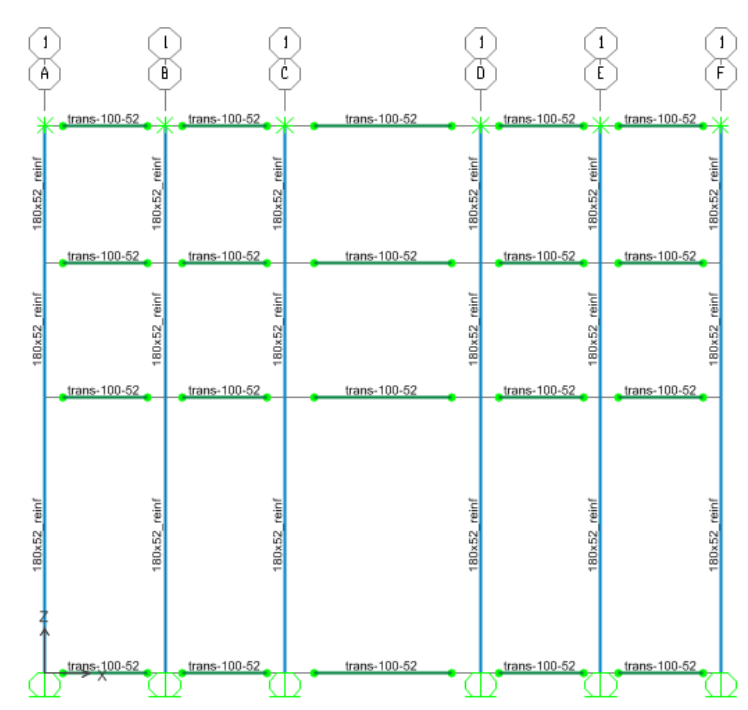

(a) Model

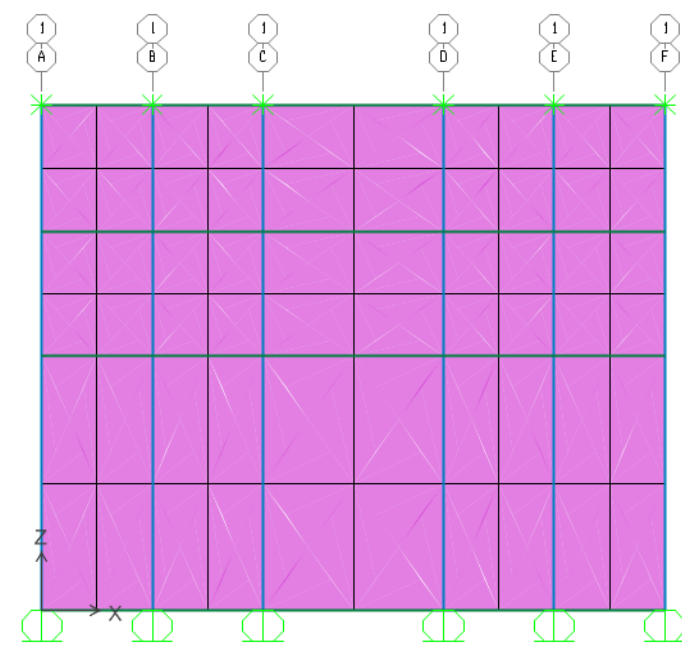

(c) Wind Loading surface

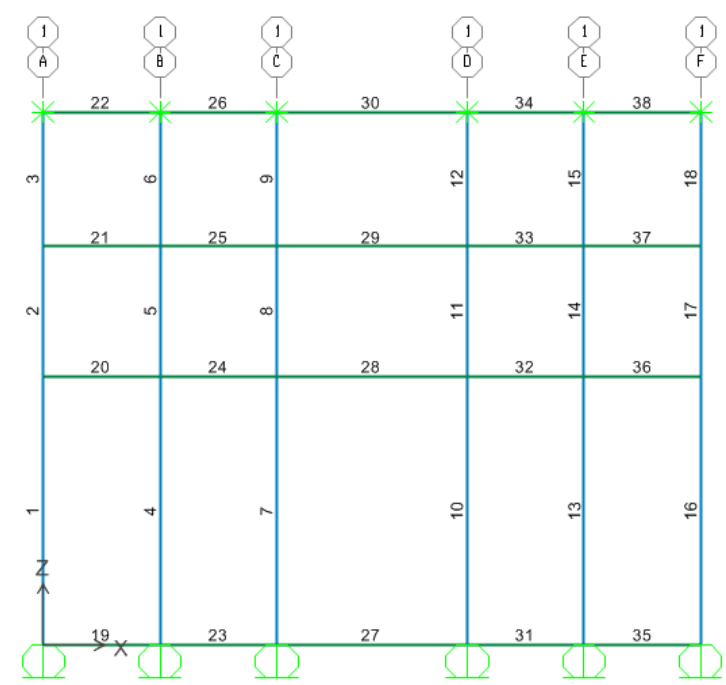

(b) Numerical Model 3D

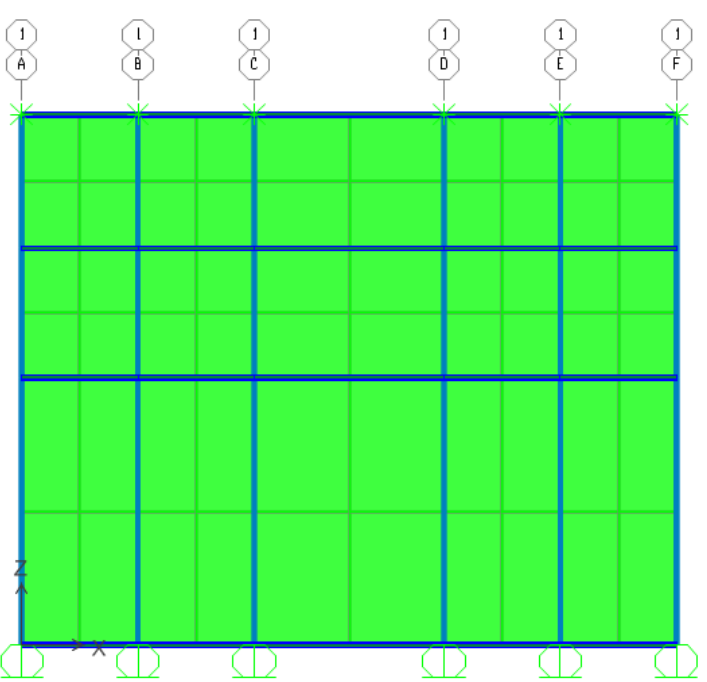

(d) Restraints condition

Figure 21. Curtain wall, (a) Model, (b) Numerical Model 3D, (c) Wind Loading surface (1.2 kpa), (d) Restraints condition.

From Figure 23 maximum Induced Stress in mullions under ULS is $40 \mathrm{Mpa}$ whereas Maximum Induced Stress in transoms under ULS is $34 \mathrm{Mpa}<$ The allowable bending stress $=160 \mathrm{Mpa}$. Maximum deflection in Mullions is $20.9 \mathrm{~mm}$. Limiting value $=\operatorname{Span} / 200=5550 / 200=27.75 \mathrm{~mm}$. In this section Louvers installed on the curtain wall located at the main entrance are addressed here.

Maximum Induced Stress in Louvers under ULS is $10 \mathrm{Mpa}$ (See Figure 24) < The allowable bending stress = $160 \mathrm{Mpa}$.

Maximum deflection in Louver Blades is $0.14 \mathrm{~mm}$ (See Figure 25), Limiting value $=\operatorname{Span} / 200=1200 / 200=6 \mathrm{~mm}$. Aluminium plates connecting the Louvers are checked and found adequate under the adopted acceptance criteria. For the adopted span (1200 mm), AF-200 blade can resist wind load of more than $2.0 \mathrm{kpa}$. 

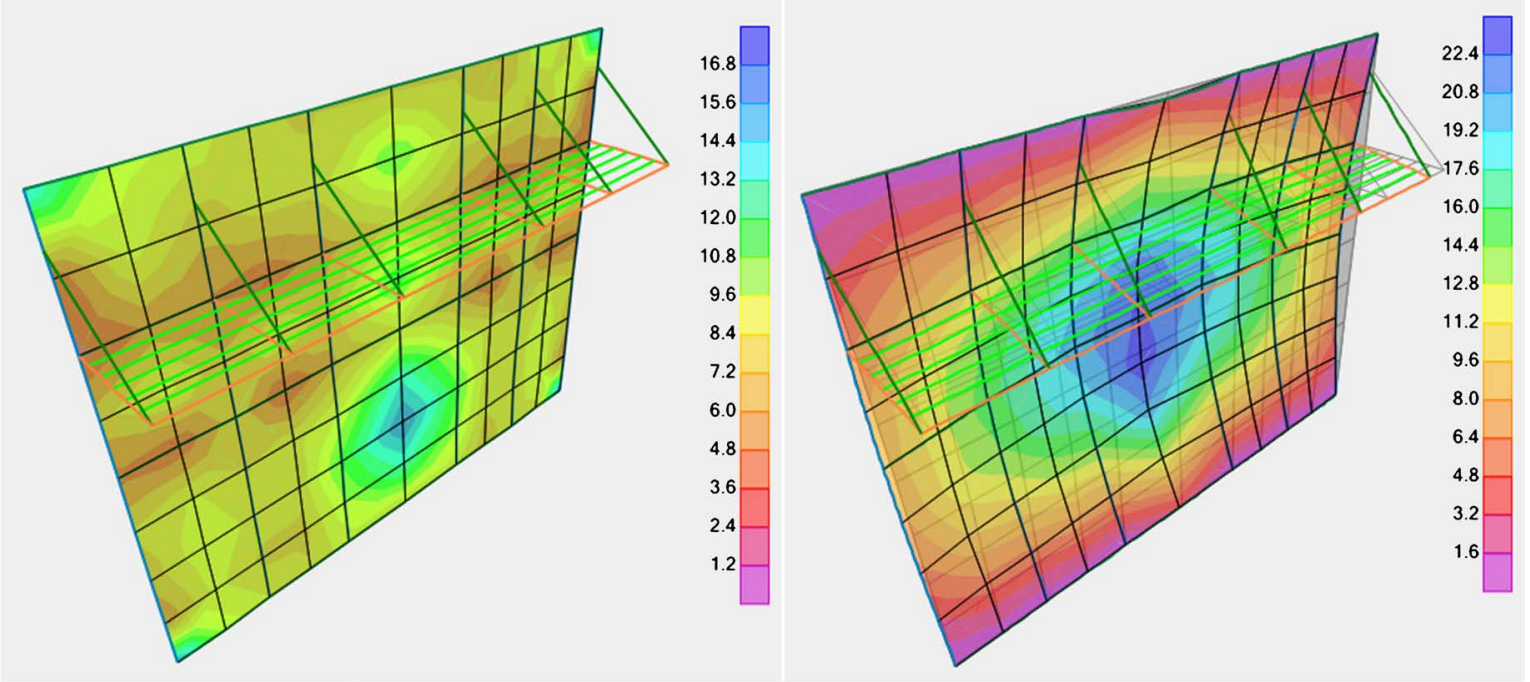

Figure 22. Stresses in Panel under ULS (left) Deflection in Panel under SLS (DL + WL) (right).
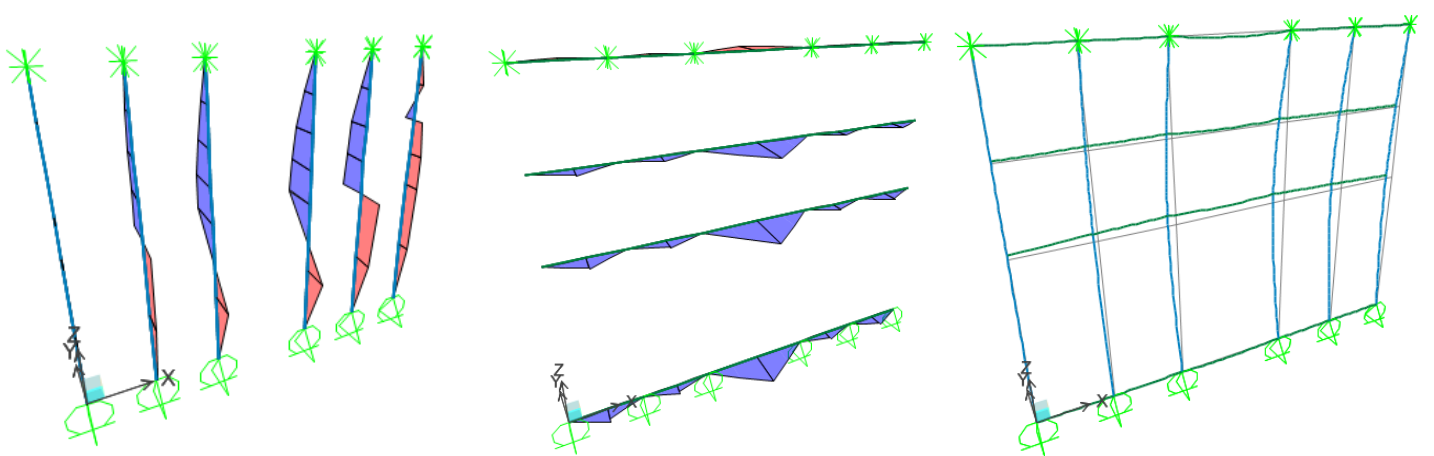

Figure 23. Stresses in Mullions (left) Stresses in Transoms (center) Deflection in Mullions and Transoms under SLS (right).

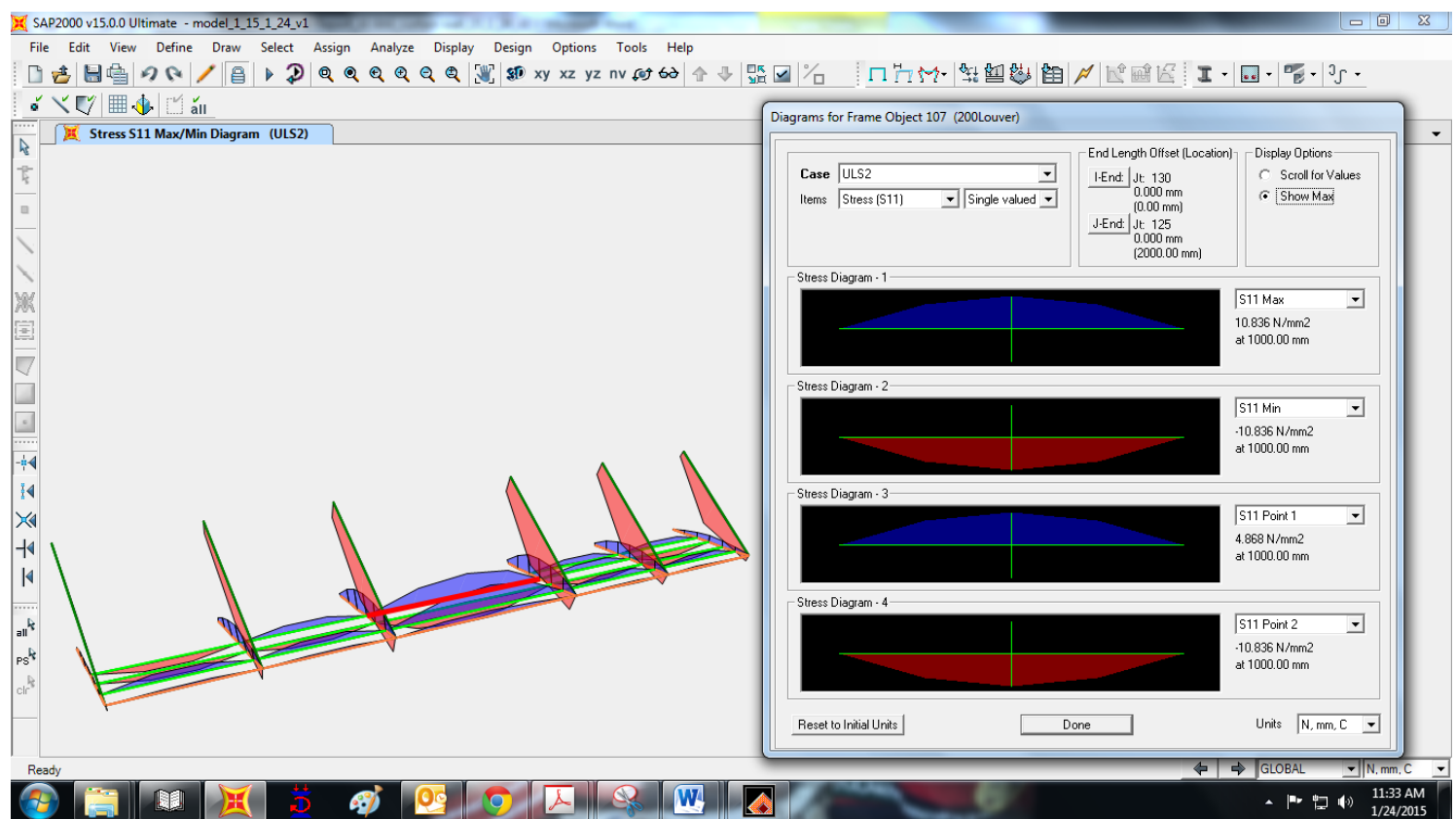

Figure 24. Stresses in Louvers (10MPa $<160 \mathrm{Mpa} \mathrm{OK})$. 


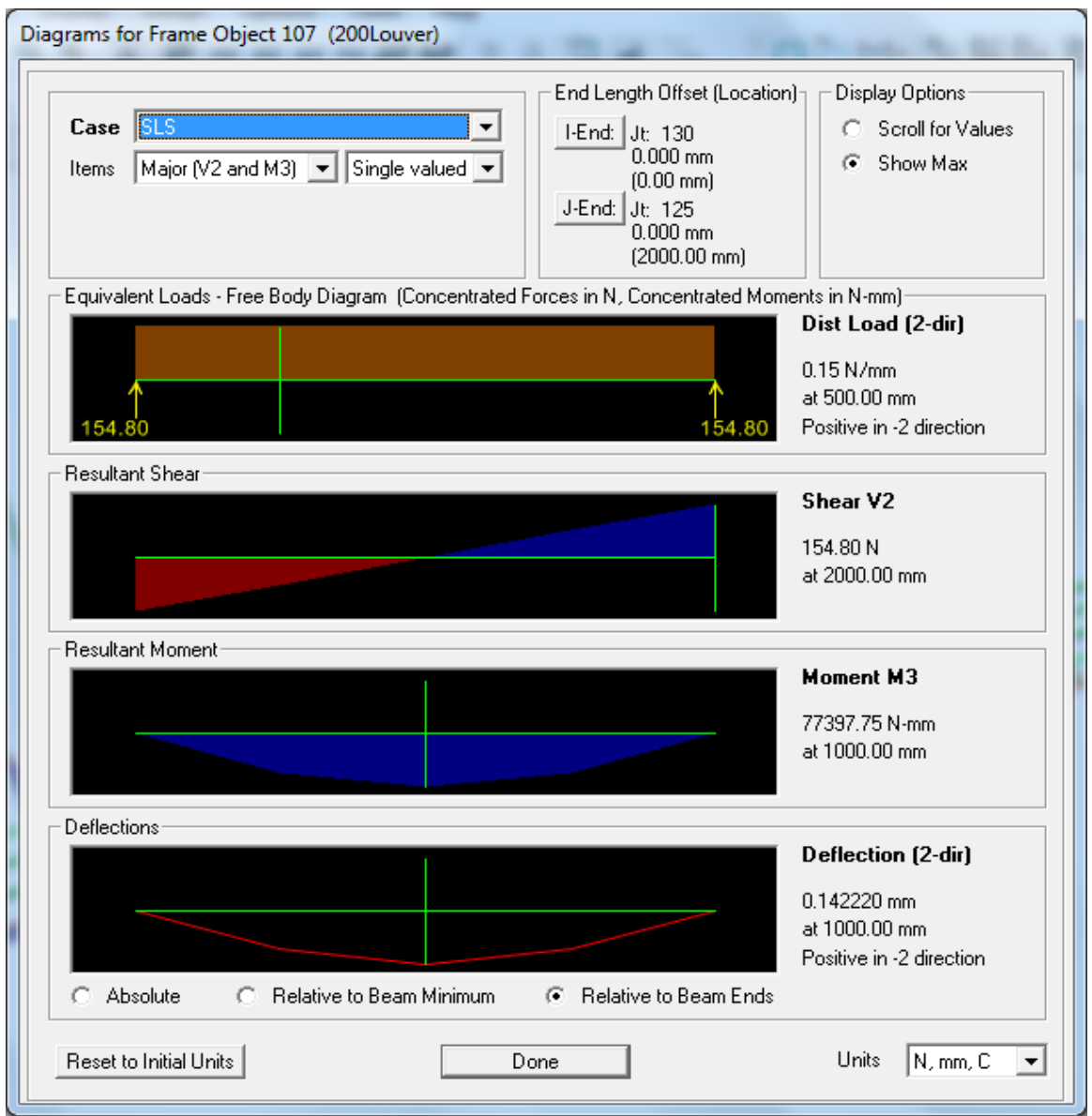

Figure 25. Defelction in Louver Blades under SLS.

\section{Conclusion}

The presented paper dealt with the analysis and consequently the design of different components related to the façade work of the sports club. Members related to different material such as structural steel, louvers, aluminum mullions and transoms, cladding panels and glass panels were analysed and design. The use of the existing structures in this case is space trusses has to carry the induced forces from the cladding structure whereas the concrete structure has to carry the applied forces from the curtain wall. It is furthermore interesting to note that such work involves many structural components to be analysed and design therefore a set of existing codes to be studied prior use them for the design. The limiting values of different codes are required to use in the design process and these values should not exceed than the project specifications. The paper shows steps and procedures to be carried out to deal with such materials. Any proposed structure has to be designed in such a way to carry its own weight in addition to the designed loading. The structural steel tubes, aluminum cladding panels, bolts, steel plates, anchor bolts, welds, glass, louvers, mullions and transoms have to satisfy strength and serviceability criteria and therefore the use of project specifications, technical catalogue, relevant codes have to studied by the techni- 
cian involved in the structural design.

\section{Conflicts of Interest}

The author declares no conflicts of interest regarding the publication of this paper.

\section{References}

[1] Muhammad, L.B. (2010) Systematic Evaluation of Curtain Wall Types. Master of Science in Architecture, Institute of Graduate Studies and Researc, Eastern Mediterranean University, Gazimağusa.

[2] Sanders, R.M. (2006) Curtain Walls: Not Just Another Pretty Façade. Journal of Architectural Technology, 23, 1-8.

[3] Sivanerupan, S., Wilson, J.L. and Gad Swinburne, E. (2011) Structural Analysis and Design of Glazed Curtain Wall Systems. Australian Journal of Structural Engineering, 12, 57-67.

[4] BS 8188-1 (1991) Structural Use of Aluminium, Part 1: Code of Practice for Design. British Standard.

[5] BS 8188-2 (1991) Structural Use of Aluminium, Part 2: Specification for Materials, Workmanship and Protection. British Standard.

[6] BS 5427-1 (1996) The Use of Profiles Sheet for Roof and Wall Cladding on Buildings. British Standard.

[7] CSI SAP V15 (2002) Integrated Finite Element Analysis and Design of Structures Basic Analysis Reference Manual. Computers and Structures, Inc., Berkeley.

[8] EN-1991-1-1 (2004) Eurocode 1, Actions on Structures-Part 1-1: General Actions -Densities, Self-Weight, Imposed Loads for Buildings. European Committee for Standardization, CEN, Brussels.

[9] EN-1990 (2002) Eurocode 0, Basis of Structural Design. European Committee for Standardization, CEN, Brussels.

[10] Muller, U. (2011) Introduction to Structural Aluminium Design. Whittles Publishing.

[11] BS 5950-1 (2000) Structural Use of Steelwork in Building. British Standard.

[12] BS 5950-2 (2001) Specification for Materials, Fabrication and Erection-Rolled and Welded Sections. British Standard.

[13] Naqash, M.T., Formisano, A. and Matteis, G.D. (2016) Aluminium Framing Members in Facades. INALCO, Trans Tech Publications, Switzerland.

[14] Naqash, M.T., Formisano, A. and Matteis, G.D. (2016) Design and Performance Testing of a Skylight in Qatar. INALCO, Trans Tech Publications, Switzerland.

[15] Naqash, M.T. (2015) A Case Study on the Structural Design of Honey Comb Core Metal Panel. The International Journal of Advanced Structures and Geotechnical Engineering, 4.

[16] Naqash, M.T. (2015) Structural Design Proposal for the Le Boulevard Skylight Doha Qatar. International Journal of Advanced Structures and Geotechnical Engineering, 4, 97-103.

[17] Chan, L. (1999) Structural Use of Glass in Buildings. The Institute of Structural Engineers.

[18] PrEN 13474-2 (2000) Glass in Building_Design of Glass Panes-Part 2: Design for 
Uniformly Distributed Loads. European Standard.

[19] PrEN 13474-3 (2009) Glass in Building-Determination of the Strength of Glass Panes-Part 3: General Method of Calculation and Determination of Strength of Glass by Testing. European Standard.

[20] Technal (2018) Technal.com-Technal.

[21] Soleil, A.B. and Airfoil, C.S. (2018) Aluminium Brise Soleil|CS Airfoil ${ }^{\odot}$. 